\title{
PENGEMBANGAN MEDIA PEMBELAJARAN MATEMATIKA DENGAN GEOGEBRA GUNA MENINGKATKAN HASIL BELAJAR MATEMATIKA SISWA
}

\author{
Neny Endriana ${ }^{1}$, Zaotul Wardi ${ }^{2}$, Najibatussakinah ${ }^{3}$ \\ ${ }^{123}$ Program Studi Pendidikan Matematika Universitas Hamzanwadi \\ ${ }^{1}$ neny.endriana@hamzanwadi.ac.id \\ ${ }^{2}$ zaowardi@gmail.com \\ 3najibatussakinahmamawaddah@gmail.com
}

\begin{abstract}
The research objective is to develop mathematics learning media with Geogebra in improving students' mathematics learning outcomes. This development uses the ADDIE model. The research was conducted at SMPN 4 Janapria with the research subjects of class VII taken randomly with a total of 25 students. The instruments used were validation sheets, practicality questionnaires from teachers and students, and learning outcomes tests. The results of the data analysis of the validity of the media obtained an actual total score of 183 and were categorized as very valid, the teacher and student response questionnaires, and the learning outcomes test were categorized as very valid and feasible to use. The quality of the practicality of the media developed met the practical criteria of teacher responses with a score of 38 and the percentage of student response scores of $88.45 \% \geq 75 \%$. The effectiveness criteria can be seen from the increase in student learning outcomes above the KKM (70) and the percentage of classical completeness $\geq 75 \%$. The pre-test data on student learning outcomes obtained a percentage value of 39.66 increasing to 78.62 based on the post test and the average posttest data score of 78.62 above the KKM with classical completeness reaching $87.50 \%$.
\end{abstract}

Keywords: Mathematics Learning Media, Geogebra, Learning Outcomes

\begin{abstract}
Abstrak
Tujuan penelitian mengembangkan media pembelajaran matematika dengan Geogebra dalam meningkatkan hasil belajar matematika siswa. Pengembangan ini menggunakan model ADDIE. Penelitian dilaksanakan di SMPN 4 Janapria dengan subjek penelitiannya kelas VII diambil secara acak sejumlah 25 siswa. Instrumen yang digunakan lembar validasi, angket kepraktisan dari guru dan siswa, dan tes hasil belajar. Hasil analisis data kevalidan media memperoleh skor total actual sebesar 183 dan berkategori sangat valid, angket respon guru dan siswa, serta tes hasil belajar berkategori sangat valid dan layak untuk digunakan. Kualitas kepraktisan media yang dikembangkan memenuhi kriteria praktis dari respon guru dengan skor 38 dan persentase skor respon siswa $88,45 \% \geq 75 \%$. Kriteria keefektifan terlihat dari meningkatnya hasil belajar siswa yang diatas KKM (70) dan persentase ketuntasan klasikal $\geq 75 \%$. Data pre test hasil belajar siswa memperoleh persentase nilai 39,66 meningkat menjadi 78,62 berdasarkan post test dan nilai rata-rata data post test sebesar 78,62 diatas KKM dengan ketuntasan klasikal mencapai 87,50\%.
\end{abstract}

Kata kunci: Media Pembelajaran Matematika, Geogebra, Hasil Belajar

Cara Menulis Sitasi: Endriana, N., \& Zaotul Wardi Najibatussakinah. (2020). Pengembangan Media Pembelajaran Matematika Dengan Geogebra Guna Meningkatkan Hasil Belajar Matematika Siswa.Mathematic Education and Aplication Journal, 2(2), 18-24.

Perkembangan ilmu pengetahuan dan teknologi berdampak pada semua kehidupan. Selain dengan perkembangan yang begitu pesat, perubahan juga terjadi dengan sangat cepat. Teknologi pada saat ini sudah menjadi bagian yang tidak dapat dipisahkan dari kehidupan manusia. Saat ini, teknologi tidak hanya digunakan sebagai sarana komunikasi, karena teknologi juga berkembang didalam bidang 
pendidikan. Pada proses belajar mengajar kita tidak bisa lepas dari teknologi, bahkan semua sistem dalam pendidikan menggunakan teknologi. Dalam Undang - undang No. 20 Tahun 2003, tentang Sistem Pendidikan Nasional, pendidikan diartikan sebagai usaha sadar yang dilakukan dan terencana untuk menciptakan suasana belajar dan proses pembelajaran supaya peserta didik secara efektif dapat mengembangkan potensi dirinya untuk memiliki kekuatan spiritual keagamaan, pengendalian diri, kepribadian, kecerdasan, akhlak mulia, serta keterampilan yang diperlukan dirinya, masyarakat bangsa dan Negara (Alkusaeri, 2013: 2).

Kurangnya penggunaan media dalam proses pembelajaran, menyebabkan siswa merasa kesulitan dalam memahami pelajaran yang disampaikan oleh guru, dikarenakan guru menjelaskan matematika kepada siswa tidak bertahap seperti tahapan yang nyata lalu ketahap yang abstrak, inilah yang meyebabkan siswa merasa tidak senang dan malas dalam belajar matematika dikarenakan rumusnya yang banyak dan contoh soal yang berbeda dengan soal latihan, sehingga menyebebkan siswa menyimpulkan sendiri bahwa matematika sebagai mata pelajaran yang menakutkan bagi siswa. Matematika dianggap memiliki tingkat kesulitan yang tinggi, namun setiap orang harus mempelajarinya karena merupakan sarana untuk memecahkan masalah sehari - hari. Pemecahan masalah tersebut meliputi penggunaan informasi, penggunaan pengetahuan tentang bentuk dan ukuran, penggunaan pengetahuan tentang menghitung dan yang terpenting adalah kemampuan melihat serta menggunakan hubungan - hubungan yang ada menurut Marti (Sundayana, 2014: 2).

Untuk menciptakan pembelajaran yang berkualitas, guru seringkali menemukan kesulitan dalam memberikan materi pembelajaran. khususnya bagi guru matematika dalam melaksanakan pembelajaran disekolah masih menunjukkan kekurangan dan keterbatasan. Terutama dalam memberikan gambaran yang konkret dari materi yang disampaikan, sehingga hal tersebut berakibat langsung kepada rendah dan tidak meratanya kualitas hasil yang dicapai oleh siswa. Kondisi ini akan terus terjadi selama guru matematika menganggap dirinya sebagai sumber belajar bagi siswa dan mengabaikan peran media. Media pembelajaran memberikan kontribusi positif dalam suatu proses pembelajaran. Pembelajaran yang menggunakan media yang tepat, akan memberikan hasil yang optimal bagi pemahaman siswa terhadap materi yang sedang dipelajarinya. Menurut Kemp (Sundayana, 2014: 3), adapun kontribusi media dalam pembelajaran sebagai berikut: (a) penyampaian pembelajaran dapat lebih terstandar; (b) pembelajaran dapat lebih menarik; (c) waktu penyampaian pembelajaran dapat diperpendek; (d) kualitas pembelajaran dapat ditingkatkan; (e) proses pembelajaran dapat berlangsung kapanpun dan dimanapun diperlukan; (f) sikap positif siswa terhadap materi pembelajaran serta proses pembelajaran dapat ditingkatkan; (g) peran guru berubah kearah yang positif .

Dari hasil wawancara bersama tiga guru yang mengajarkan mata pelajaran matematika di sekolah SMPN 4 Janapria menyatakan bahwa, dalam mengajarkan matematika guru tidak menggunakan komputer sebagai media yang digunakan dalam menyampaikan materi bangun datar 
terutama menggunakan media pembelajaran geogebra. Guru dalam mengajarkan matematika kepada siswa hanya menggunakan alat peraga yang sangat sederhana, akan tetapi siswa masih kurang aktif dalam proses belajar dan komunikasi antara guru dan siswa kurang terjalin. Didalam mengajar guru menggunaka beberapa buku dan internet yang dijadikan sebagai sumber dalam proses pembelajaran. Dan hasil belajar matematika siswa masih rendah.

Salah satu software yang dapat digunakan dalam mengajarkan matematika terkait dengan sifatnya yang abstrak adalah dengan menggunakan software geogebra. Geogebra merupakan perangkat lunak matematika yang dinamis, bebas, dan multi-platform yang menggabungkan geometri, aljabar, tabel, grafik, dan kalkulus dalam satu lingkup yang mudah dan dapat digunakan untuk semua jenjang pendidikan. Dinamis artinya pengguna dapat menghasilkan aplikasi matematika yang interaktif. Bebas artinya geogebra dapat digunakan dan termmasuk perangkat lunak sehingga setiap orang dapat mengubah atau memperbaiki programnya. Multi-flatform berarti geogebra tersedia untuk segala jenis komputer sepeerti PC, Tablet dan berbagai sistem yang ada dikomputer seperti Windows, Max OS, Linux dan sebagainya (Hidayat \& Tamimuddin, 2016). Sesuai dengan namanya, Geogebra dapat digunakan untuk belajar (visualisasi, komputasi, eksplorasi dan eksperimen) dan mengajar materi geometri, aljabar, dan kalkulus. Geogebra dapat digunakan untuk menggambar titik, ruas garis, vektor, garis, polygon, irisan kerucut, dan kurva dua dimensi (Harisuddin, 2019: 4), dengan memanfaatkan software geogebra guru diharapkan bisa menciptakan pembelajaran yang inovatif dikelas. Dengan demikian hasil belajar siswa dapat ditingkatkan.

\section{METODE}

Penelitian ini menggunakan pendekatan penelitian dan pengembangan atau Research and Development (R\&D).Jenis pengembangan ini berorientasi menghasilkan dan menguji sebuah produk. Penelitian pengembangan ini menggunakan model pengembangan ADDIE yang merupakan singkatan dari Analisis, Design, Development or Production, Implementation or Delivery and Evaluations. Adapun dipaparkan langkah-langkah model ADDIE yang dijelaskan oleh Mulyatiningsih (2012: 200) sebagai berikut:

1. Analysis (Analisis)

Pada tahap ini, kegiatan utama adalah menganalisis perlunya pengembangan media pembelajaran geogebra dan menganalisis kelayakan dan syarat-syarat pengembangan media baru.

2. Design (Desain)

Hasil pada tahap ini berupa rancangan buku panduan media pembelajaran dengan geogebra dan media pembelajaran geogebra. Selain itu, akan dirancang pula angket untuk mengetahui respon siswa dan guru untuk mengukur kepraktisan instrumen serta tes untuk mengukur hasil belajar matematika siswa. 
3. Development (Pengembangan)

Karena pada tahap desain telah dirancang media pembelajaran geogebra maka pada tahap pengembangan ini disiapkan perangkat pembelajaran menggunakan media pembelajaran geogebra diantaranya buku panduan, RPP, materi ajar, dan LKPD. Dan pada tahap ini pula dilakukan proses validasi produk termasuk instrumen tes dan angket. Hasil dari validasi produk berupa data skor tanggapan ahli dikonversikan menjadi data kualitatif skala lima dengan acuan rumus yang diadaptasi dari Sa'adun Akbar (2013: 73), sedangkan untuk validasi instrumen menggunakan validitas Aiken yang diadaptasi dari Retnawati (2016: 18).

4. Implementation (Penerapan)

Penerapan merupakan kegiatan menggunakan produk atau media yang telah dikembangkan pada kondisi nyata yaitu dikelas. Subjek penelitian ini adalah siswa kelas VII di SMPN 4 Janapria.

5. Evaluation (Evaluasi)

Pada tahap evaluasi ini, peneliti melakukan perbaikan (revisi) produk apabila belum mencapai kriteria praktis dan efektif berdasarkan acuan kriteria kepraktisan dan keefektifan yang sudah ditetapkan. Data mengenai kepraktisan media pembelajaran didapatkan dari angket respon guru dan angket respon siswa. Hasil angket respon guru berupa data skor dikonversikan menjadi data kualitatif skala lima, dengan acuan rumus yang diadaptasi dari Sa'adun Akbar (2013: 73) dan untuk hasil respon siswa dianalisis dengan mencari persentase skor dan mencocokkannya dengan acuan rumus yang diadaptasi dari Sa'adun Akbar (2013: 83). Data mengenai keefektifan model pembelajaran diperoleh dari hasil analisis terhadap skor hasil belajar matematika siswa. Skor yang diperoleh siswa dianalisis menggunakan rumus acuan yang diadaptasi dari Sa'adun Akbar (2013: 95). Sementara untuk model tersebut dikatakan efektif apabila skor tes hasil belajar siswa rata-ratanya $\geq 70$ dan persentase ketuntasan $\geq 75 \%$ siswa mencapai KKM (70).

\section{HASIL DAN PEMBAHASAN}

Media pembelajaran berupa aplikasi geogebra disusun dalam bentuk buku panduan telah divalidasi oleh 3 orang ahli. Hasil dari validasi kemudian dianalisis dan hasil akhirnya diperoleh sebagai berikut.

Tabel 1. Hasil validasi Media

\begin{tabular}{|c|c|}
\hline Validator & Skor \\
\hline I & 58 \\
\hline II & 62 \\
\hline III & 63 \\
\hline Skor Total Aktual & 183 \\
\hline Kategori & Sangat valid \\
\hline
\end{tabular}

Sumber: Lembar Validasi Media 
Berdasarkan hasil validasi yang tercantum pada tabel 1 diatas, dapat disimpulkan bahwa media pembelajaran matematika dengan Geogebra mencapai kriteria sangat valid sesuai dengan kriteria kevalidan media yang sudah ditentukan.

Penilaian kevalidan angket respon guru dan angket respon siswa divalidasi oleh 3 orang ahli. Hasil penilaian yang diberikan selanjutnya dianalisis sesuai dengan langkah-langkah yang sudah ditetapkan. Adapun hasil dari analisis kevalidan angket respon guru dan siswa dapat dilihat pada tabel 2 berikut ini:

Tabel 2 Hasil Validasi Angket Respon Guru

\begin{tabular}{|c|c|c|}
\hline Media & $\begin{array}{c}\text { Angket Respon Guru } \\
\text { (Skor) }\end{array}$ & $\begin{array}{c}\text { Angket Respon Siswa } \\
\text { (Skor) }\end{array}$ \\
\hline Validator I & 31 & 53 \\
\hline Validator II & 38 & 70 \\
\hline Validator III & 35 & 58 \\
\hline Skor Total Aktual & 104 & 181 \\
\hline Kategori & Sangat valid & Sangat valid \\
\hline
\end{tabular}

Sumber: Lembar Validasi Angket Respon Guru dan siswa

Berdasarkan hasil dari analisis, dapat disimpulkan bahwa Media pembelajaran matematika dengan Geogebra mencapai kriteria sangat valid sesuai dengan kriteria interval kevalidan angket respon guru dan siswa yang sudah ditetapkan.

Angket kepraktisan ini diberikan kepada guru matematika dan siswa kelas VII di SMPN 4 Janapria setelah menggunakan media pembelajaran dengan aplikasi geogebra. Hasil penilaian dari guru dan siswa menunjukkan penerapan media pembelajaran dengan aplikasi geogebra yang telah dikembangkan sudah praktis yang bisa dilihat pada tabel 3 berikut.

Table 1 Hasil Penilaian Kepraktisan Dari Guru Dan Siswa

\begin{tabular}{|c|l|c|c|}
\hline No & & Respon dari Guru & Respon siswa \\
\hline 1 & Jumlah Responden & 2 & 25 \\
\hline 2 & Jumlah Pertanyaan & 8 & 15 \\
\hline 3 & Jumlah Skor & 39 & 322 \\
\hline 4 & Persentase skor & - & $90,45 \%$ \\
\hline 5 & Kriteria & Praktis & Praktis \\
\hline
\end{tabular}

Penilaian kevalidan tes hasil belajar siswa divalidasi oleh 3 orang ahli. Hasil penilaian yang diberikan selanjutnya dianalisis sesuai dengan langkah-langkah yang sudah ditetapkan. Adapun hasil dari analisis kevalidan angket respon guru dan siswa dapat dilihat pada tabel 4 berikut ini: 
Tabel 4 Hasil validasi Tes Hasil Belajar

\begin{tabular}{|c|c|}
\hline Validator & Skor \\
\hline I & 39 \\
\hline II & 50 \\
\hline III & 50 \\
\hline Skor Total Aktual & 139 \\
\hline Kategori & Sangat valid \\
\hline
\end{tabular}

Sumber: Lembar Validasi THB

Berdasarkan hasil validasi yang tercantum pada tabel 4 diatas, dapat disimpulkan bahwa media pembelajaran matematika dengan Geogebra mencapai kriteria sangat valid sesuai dengan kriteria kevalidan Tes Hasil Belajar yang sudah ditetapkan.

Berdasarkan hasil perolehan skor dari pemberian tes hasil belajar matematika siswa pada 25 siswa sebelum menggunakan media pembelajaran matematika dengan Geogebra (data pre test) dan sesudah penggunaan media pembelajaran matematika dengan Geogebra menunjukkan terjadinya peningkatan hasil dan efektif digunakan. Hal ini dapat dilihat pada tabel berikut.

Tabel 5 Data Pre Test dan Post Test Hasil Belajar Siswa Kelas VIIIC

\begin{tabular}{|c|l|c|c|c|c|}
\hline No & \multicolumn{1}{|c|}{ Aspek } & Pre Test & Keterangan & Post Test & Keterangan \\
\hline 1 & Rata-rata & 38,75 & $\begin{array}{c}\leq \\
\text { KKM (70) }\end{array}$ & 78,52 & $\geq$ KKM (70) \\
\hline 2 & Persentase skor & $38,75 \%$ & Tidak tinggi & $78,52 \%$ & tinggi \\
\hline 3 & $\begin{array}{l}\text { Persentase } \\
\text { ketuntasan } \\
\text { klasikal }\end{array}$ & $0 \%$ & $\begin{array}{c}\text { Tidak Efektif } \\
(\leq 75 \%)\end{array}$ & $88,50 \%$ & $\begin{array}{c}\text { Efektif } \\
(\geq 75 \%)\end{array}$ \\
\hline
\end{tabular}

\section{KESIMPULAN}

Dari hasil penelitian dan pengembangan media pembelajaran matematika dengan Geogebra yang telah dilakukan di siswa kelas VII SMPN 4 Janapria, diperoleh data yang menunjukan bahwa media pembelajaran matematika dengan aplikasi Geogebra yang dikembangkan telah memenuhi kriteria valid, praktis, dan efektif sehingga dapat dikatakan media pembelajaran matematika dengan Geogebra layak digunakan. Sehingga disimpulkan secara umum bahwa media tersebut layak digunakan sebagai media pembelajaran matematika di kelas VII SMP/MTs. Adapun saran yang dapat diajukan pada penelitian antara lain guru dapat mengembamgkan kembali media pembelajaran matematika khususnya geogebra pada materi pembelajaran yang lain,sehingga pembelajaran akan menjadi semakin menyenangkan, dapat meningkatkan pemahaman konsep dalam belajar matematika sehingga siswa tidak cepat merasa bosan dalam belajar matematika, dan diharapkan dapat melanjutkan dan mengembangkan penelitian ini dengan cakupan yang lebih luas dan hasil yang lebih baik. 


\section{DAFTAR PUSTAKA}

Akbar Sa'dun. (2013). Instrumen Perangkat Pembelajaran. Bandung: PT Remaja Rosdakarya.

Alkusaeri, Irzani. (2013). Pengembangan Program Pembelajaran Matematika. Jawa Tengah.:Sukses Mandiri Press

Annafi Nurfidianty \& Sry Agustina. (2018). Pengembangan model pembelajaran project based learning (pbl) melalui kearifan lokal untuk mempersiapkan calon pendidik yang berbudaya. Bima : Jurnal Inovasi Pendidikan Sains, Vol. 9, No.1, Hal. 2.

Hidayat, Fadjar Noer dan Tamimuddin, Muh. (2016). Pemanfaatan Aplikasi Geogebra Untuk Pembelajaran Matematika. Pusat Pengembangan dan Pemberdayaan Pendidik dan Tenaga Kependidikan Matematika, Direktorat Jendral Guru dan Tenaga Kependidikan.

Sugiyono. (2013). Metode penelitian pendidikan. Bandung: CV. Alfabeta . (2010). Statistika Untuk Penelitian. Bandung:CV. Alfabeta

Sundayana, Rostina. (2014). Media Dan Alat Peraga Dalam Pembelajaran Matematika. Bandung: CV. Alfabeta.

Warsono \& Hariyanto. (2012). Pembelajaran Aktif. Bandung : PT Remaja Rosdakarya

Harisuddin, Muhammad Iqbal. (2019). Asyiknya Belajar Matematika dengan Geogebra. Sleman: CV. Budi Utama.

(Endriana \& Zaotul Wardi Najibatussakinah, 220 C.E.)

Endriana, N., \& Zaotul Wardi Najibatussakinah. (220 C.E.). hgti. Eduction, 1, 2-6. 